\title{
Clusters of Entrepreneurship and Innovation
}

\section{Citation}

Chatterji, Aaron K., Edward Glaeser, and William Kerr. "Clusters of Entrepreneurship and Innovation." Harvard Business School Working Paper, No. 13-090, April 2013. (NBER Working Paper Series, No. 19013, April 2013.)

\section{Permanent link}

http://nrs.harvard.edu/urn-3:HUL.InstRepos:10646423

\section{Terms of Use}

This article was downloaded from Harvard University's DASH repository, and is made available under the terms and conditions applicable to Open Access Policy Articles, as set forth at http:// nrs.harvard.edu/urn-3:HUL.InstRepos:dash.current.terms-of-use\#OAP

\section{Share Your Story}

The Harvard community has made this article openly available.

Please share how this access benefits you. Submit a story.

\section{Accessibility}


H A R VAR D

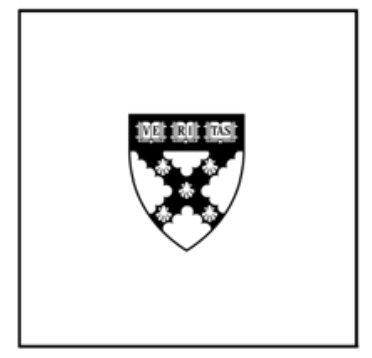

\title{
Clusters of Entrepreneurship and Innovation
}

\author{
Aaron Chatterji \\ Edward Glaeser \\ William Kerr
}

\section{Working Paper}

13-090

April 25, 2013 


\title{
Clusters of Entrepreneurship and Innovation
}

\author{
Aaron Chatterji, Edward Glaeser, William Kerr
}

April 2013

\begin{abstract}
This paper reviews recent academic work on the spatial concentration of entrepreneurship and innovation in the United States. We discuss rationales for the agglomeration of these activities and the economic consequences of clusters. We identify and discuss policies that are being pursued in the United States to encourage local entrepreneurship and innovation. While arguments exist for and against policy support of entrepreneurial clusters, our understanding of what works and how it works is quite limited. The best path forward involves extensive experimentation and careful evaluation.
\end{abstract}

Keywords: Entrepreneurship, innovation, agglomeration, cluster, place making.

JEL Classification: H70, L26, L52, L53, M13, O25, O38, R00, R10, R12, R50

Author institutions and contact details: Chatterji: Duke University, ronnie@duke.edu; Glaeser: Harvard University and NBER, eglaeser@harvard.edu; Kerr: Harvard University and NBER, wkerr@hbs.edu.

Acknowledgments: This paper has been prepared for the Innovation Policy and the Economy Forum, April 2013. We thank Josh Lerner, Erin Scott, and Scott Stern for helpful comments. 


\section{Introduction}

For many decades, the common wisdom among local officials pursuing employment growth for their areas was to attract a large firm to relocate. This "smokestack chasing" led to many regional governments bidding against each other and providing substantial incentives to large plants making their location choice decisions (e.g., Greenstone et al. 2010). The success of entrepreneurial clusters in recent decades, however, has challenged this wisdom, and now many policy makers state that they want their regions "to be the next Silicon Valley." This has led to extensive efforts to seed local entrepreneurship (e.g., Lerner 2009), with today's politicians routinely announcing the launch of an entrepreneurial cluster in a hot industry, such as biotechnology, nanotechnology, or advanced manufacturing. In this paper, we explore the rationale for and efficacy of policies to promote local entrepreneurship and innovation and reflect on recent initiatives in this domain.

Section 2 provides a conceptual introduction to industrial/innovation policy that grounds the later empirical discussions. The move away from smokestacks to small-scale entrepreneurship is understandable given the strong correlation between small establishment size and local economic development (Glaeser et al. 2010, 2012). Section 3 discusses the link between entrepreneurship and innovation and local economic growth. Figure 1 highlights a representative graph from this work taken from Glaeser et al. (2012). The horizontal axis of each panel provides a potential way to measure entrepreneurship around 1982, and the vertical axis of each panel measures the employment growth of the city during 1982-2002. There is a very strong connection between initial entrepreneurship and subsequent employment growth. While striking, there could be many factors behind this correlation, and we discuss the existing, but still nascent, evidence in order to establish causal connections. We also identify some recent studies that look at the impact of local innovation on regional economic performance.

While it is possible to have pro-entrepreneurship policies that are not tied to clustermaking, supporting a cluster of small-scale entrepreneurs allows policy makers to affect many entrepreneurs simultaneously, providing important scale to their policy interventions, and appears to respect the empirical tendency of economic activity to cluster. Section 4 reviews the extent to which we see economic activity spatially concentrated. Clusters of related businesses exist in most sectors of the economy and have been present throughout modern economic history. We further discuss the extent to which forms of high-impact entrepreneurship (e.g., venture capital) and patenting display additional concentration above and beyond that of general economic activity. 
Section 5 then turns to the local traits of places that correspond to higher entrepreneurship levels. Relative to the literature that seeks to link local entrepreneurship to growth, the literature on spatial determinants of entrepreneurship in Section 5 is more established. We review factors that have been found important at the city level: education, age structure, local entrepreneurial culture, and physical infrastructure. We also consider evidence regarding industry linkages within cities, such that the local industrial composition favors start-ups in one sector over another, and the role of skilled immigrants for spatial variations in innovation levels and entrepreneurship for technical fields. At the end of this section, we discuss some open questions about access to cluster benefits with which researchers are currently grappling.

Section 6 discusses recent policy initiatives at the federal and local level to encourage entrepreneurship and innovation. We first outline some of the goals of these policies, especially as they relate to entrepreneurship and innovation. We highlight the variety of recent efforts to increase the "local supply" of entrepreneurs, especially through education initiatives, or the availability of entrepreneurial finance. We also review the varied role of policy in the development of three well-known innovative clusters: Silicon Valley, Boston's Route 128 corridor, and North Carolina's Research Triangle Park. A common theme in many of these discussions is the importance of correct baseline business environments, or "setting the table" activities, relative to targeted interventions. Finally, we discuss the recent emphasis on promoting high-growth entrepreneurship at the federal level. We close the paper with some conclusions and a call for further experimentation on this important question.

\section{Industrial Policy, Entrepreneurship and Clusters}

Since Alexander Hamilton wrote his "Report on Manufactures," American governments have tried to actively prod one or more sectors of the economy to grow. There is an even stronger tradition of industrial policy outside of the United States. Sometimes these policies are justified by an obvious market failure, but often they reflect a public desire to appear to be doing something to engineer economic growth from the top down.

While it is hard to clearly document whether the benefits of industrial policy exceed the costs, it is easy to provide plausible stories that justify public interventions to aid new or old industries in declining areas or in areas that are just taking off. Three classes of justification are more common: externalities, redistribution, and credit constraints. First, entrepreneurship or industrial policy helps internalize externalities. If governments will benefit from taxes paid by a successful firm in the future, then it may make sense to aid the firm up front with public subsidy: tax breaks to million-dollar plants can be seen as an up-front payment compensating the plant for the future taxes that the local government will extract from them. 
Real externalities can also exist that justify interventions. Hamilton himself was eager to subsidize the import of technical knowledge, which would presumably spread throughout the country. If there are human capital externalities (Rauch 1993), and if industrial policy builds human capital, then this may have beneficial results throughout the region. The existence of industrial clusters seems to suggest that there are externalities across firms, which provides intellectual support to policies that encourage industries. Of course, those clusters may not reflect real externalities at all, but unobserved geographic advantages to particular locales (Ellison and Glaeser 1997) or just cost savings from reduced transportation costs.

The redistributive aim of industrial policy is best seen in the "Empowerment Zones" program and the Appalachian Regional Commission in the United States, the "Enterprise Zones" program in the United Kingdom, and the numerous European policies meant to bolster declining regions. These policies are seen as tools for fighting centralized poverty by encouraging nearby business formation. Economists often question whether it makes sense to help poor placesrather than poor people - but there is some limited evidence suggesting that Empowerment Zones, at least, have provided some benefits for local residents (Busso et al. 2012).

A final, popular justification for policies that particularly benefit smaller firms is that there exist credit market imperfections that somehow make it difficult to fund worthy start-ups (Kerr and Nanda 2011) or that certain entrepreneurs are discriminated against in these credit markets (Chatterji and Fairlie 2012), and that government aid can solve this problem. While it is assuredly true that not every profitable project is funded, it is hard to see exactly how the government has any comparative advantage as a venture capitalist (Lerner 2002). Nonetheless, the public sector has provided either loan guarantees or direct lending to various entrepreneurs.

Credit market interventions can be justified directly if there are credit market imperfections. In the first two cases of support being justified due to externalities or redistribution concerns, the optimal means of providing a subsidy may still take the form of a loan. If the government's risk tolerance and patience are higher than that of the subsidized entrepreneur, then the optimal subsidy can easily take the form of aid that is largely repaid upon a good outcome. Loans or loan guarantees have the added advantage, from the public official's perspective, of not seeming like a direct outlay of taxpayer money.

These justifications are relevant for any kind of industrial policy, but our focus here is on local policies towards innovation and entrepreneurship. We therefore ignore national policies such as tariffs, immigration policy, and patent policy, and we focus on support for industry and entrepreneurship at the local level. This aid can take the form of direct subsidies (including tax abatement), non-priced public infrastructure, and credit support (including both loan guarantees and direct lending). 
Figure 2 highlights two key policy choices: specificity of location and specificity of aid recipient. Industrial or entrepreneurship policy occurs at different levels of geography-nation, region, state, city, or neighborhood. The policies can also be economy-wide, specific to industries or sectors, or even focused on particular firms. The largest determinant of the degree of geographic specificity is the geographic reach of the governmental unit itself. Nations make national policies, while cities make policies within their own borders. But there are cases, like the Appalachian Regional Commission or Empowerment Zones, where a nation focuses on the region or the neighborhood. Indeed, since neighborhood-level governments are essentially nonexistent in the United States, any neighborhood-level policy reflects the decision of a larger government to target resources towards a specific area.

The decision to go local and focus on clusters can reflect a redistributive impulse, as in the Empowerment Zones federal program, or cost-related concerns about infrastructure. As an example of scarce infrastructure resources, new subways stops cannot go everywhere, so they go to a specific locale and support businesses in that area. But modern cluster policy also reflects a sense that there are strong local externalities that can be coordinated by a governmental entity that connects different firms.

We discuss the evidence on local externalities and geographic clusters in Section 3, but it is worth stressing in advance that even if such externalities are real and powerful, they may not justify attempts to concentrate economic activity. For example, one can imagine a scenario where each entrepreneur benefits his or her neighbors, but there are decreasing returns to such spillovers. That is, the first hundred entrepreneurs in the area are critical, but the next hundred do not add that much more. In this scenario, it may make sense to spread those entrepreneurs out rather than consolidating them in one place. The case for clustering policies is stronger when there are important increasing returns in the nature of local spillovers (Glaeser and Gottlieb 2008). This scenario would occur if bringing all two hundred entrepreneurs together would provide more benefit than keeping them in two separate locations.

Governments choose industrial specificity along with geographic specificity. All governments make general public policies that impact the economy-our interest lies in policies that focus on specific industries or sectors. One choice is to focus on specific industrial groups, as Hamilton wanted a focus on manufacturing as opposed to agriculture. Typically, local governments choose industry-specific policies to target fields that appear to have a long-standing comparative advantage in the city, such as fashion or finance in New York, or industries that seem to be poised for growth in the future, like the life sciences. The focus on novel sectors is often justified as reflecting the new ideas and human capital that can be created by these sectors. The economic case for subsidizing specific industries typically relies on documenting that these industries have obvious positive externalities. As an example, support for green energy is seen as 
a tool for dealing with the negative externalities, like carbon emissions, associated with traditional energy sources.

Along with the choice of old versus new industry, governments can also choose whether to focus policy on old or new firms. While this can be done firm-by-firm, as we discuss next, it can also be done with more general policies. For example, a shift from local labor taxes to business taxes will tend to favor start-ups over mature industries, since profits are rare in new firms but those firms still typically have to pay their workers. Tougher regulations on new entry will tend to favor incumbents over start-ups. The removal of non-compete clauses (Fallick et al. 2006, Marx et al. 2009) will tend to favor start-ups over incumbents.

When we turn to firm-by-firm policies, there is always discretion over industry and maturity. Often those firm-level policies work either through loans or tax abatements at the local level, and they can be the expression of policies which were originally designed to operate at a sector level. The Energy Department's loan guarantees that supported Solyndra, for example, reflected a national decision to support green energy more generally. The State of Massachusetts' decision to support Evergreen Solar reflected a similar state-wide priority.

The perpetual local game of attracting million-dollar plants is the classic example of local, firm-by-firm policy. We include these decisions as reflecting city-level, rather than neighborhood-level, policies in Figure 2, but in some cases, the appeal of a specific firm is that it will put a physical plant in a specific, perhaps blighted, area. In many cases, these policies simply reflect the political reality that a plant that is of sufficient importance to the political jurisdiction will be able to bargain its way towards privileged treatment.

The case for firm- versus industry-level policies, assuming that either such policy makes sense, depends on the degree of confidence in local competence and impartiality. If local governments have the capacity to select firms that bring particularly large local benefits and the incorruptibility to ensure that their aid does not just flow to the well-connected, then firm-level policies enable them to target subsidies more efficiently. If local governments are not good at picking winners or are likely to be swayed by less lofty motives, then such discretion can be quite counter-productive. Economists, who are persuaded by the historical track record to be skeptical about governments, typically argue against firm-specific policies.

Cluster policies for entrepreneurship and innovation occupy a very distinct place in this scheme. They are narrowly place-specific, favoring a very specific locale, such as Boston's Innovation District. This geographic concentration is justified both as a tool for generating positive externalities and as a means of getting the most out of scarce infrastructure dollars. They are also oriented towards either specific industrial sectors (life science, computers) or more generally towards start-ups. They are not usually firm-specific, largely because start-ups are too 
small to address on a firm-by-firm basis, but also because the proponents of these policies often share economists' skepticism about the ability to pick winning firms, even though they believe in the ability to pick winning sectors.

As we turn to the empirical results, therefore, we ask whether the track record shows that there are benefits from supporting smaller rather than larger firms, whether there are benefits from engineering clusters, and which local attributes typically attract entrepreneurs. We will spend less time on the empirical track record of industry-specific support.

\section{Entrepreneurship, Innovation and Local Growth}

Before turning to factors that promote or discourage entrepreneurship and innovation in a local area, we first review the academic literature on the economic consequences of these forces. While some academics and policy makers assume from the start that more entrepreneurship and innovation are good for the local area, this relationship has been difficult to pin down due to the endogeneity of both forces. While there is little debate over the correlation between local growth and smaller, younger firms, that correlation may reflect a tendency of rapidly growing areas to attract new firms rather than the impact of start-ups on local growth. These issues make interpretation of typical evidence like Figure 1 difficult. Moreover, it is quite possible to imagine that some places have assets, like strong research universities or pro-business policies, that engender growth and attract start-ups.

Some older studies provide multivariate correlations between these factors, but empirical work seeking causal assessments are remarkably few in number. We discuss the state of the academic literature, with the most important conclusion being that much more work is needed in this regard.

The intellectual tradition behind Figure 1 and similar observations about entrepreneurship's role for urban success dates back to Chinitz's (1961) comparison of New York and Pittsburgh. Chinitz believed that Pittsburgh's dearth of entrepreneurs in the 1950s reflected its historical concentration in the steel industry, which had significant returns to scale and potentially crowded out more entrepreneurial activities. Chinitz suggested that this dampening of entrepreneurship came through both static factors (e.g., access to inputs or financial capital for new businesses) and dynamic factors (e.g., the transmission of skills and attitudes from parents to children). By contrast, Chinitz saw in New York a vibrant entrepreneurship impetus descending from the city's early work in the decentralized garment industry, and Chinitz argued that this industrial pedigree helped explain why New York was growing faster than Pittsburgh. While his analysis pointed to the power of local cultures of 
entrepreneurship, Chinitz refrained from making any strong policy recommendations related to that conclusion.

This notion of differences across places in entrepreneurial culture - and in particular the link these differences have to regional performance - has also been famously put forward in recent years by Saxenian (1994) when contrasting the regional performance of Boston and Silicon Valley. Saxenian argues that the regional structure and entrepreneurial culture of Silicon Valley allowed it to displace Boston as the center for semiconductor manufacturing in the second half of the $20^{\text {th }}$ century, despite Boston's dominance and perceived advantages after World War II. The role of public policy looms large in Saxenian's work, most notably the role of the defense industry in building up both areas. But again, Saxenian refrains from urging local policies meant to duplicate the complex cocktail of cooperative competition that she observed in Silicon Valley.

More systematic empirical evidence confirms that a general correlation lies behind these famous case studies. For example, Glaeser et al. (1992) find a strong correlation between small establishment size and subsequent employment growth across sectors within U.S. cities. Glaeser et al. (2010) also document the strength of this relationship when modeling entrepreneurship through other metrics like the city's employment in entering businesses and when looking at industries within cities. Similar conclusions are reached by Delgado et al. (2010a,b), Rosenthal and Strange (2003, 2010), and Gennaioli et al. (2012).

The first beachhead for developing causal assessments of the real effects of entrepreneurship focused on venture capital (VC) financing, rather than entrepreneurship itself. This was an attractive starting point because it was easier to identify exogenous shocks in VC financing; moreover, data on VC financing were more readily linked to data on outcomes like employment or patenting, without necessarily needing to observe the middle step of entry rates, where data collection was much harder. Kortum and Lerner (2000) analyze industries, while Samila and Sorenson (2011) consider cities. The latter paper is closest to the spatial spirit of this review, and the study finds modest employment growth roles for $\mathrm{VC}$ financing using variation across U.S. cities. The work suggests that doubling the VC activity in a typical city would lead to about a $1 \%$ increase in number of jobs and that these jobs would be higher skilled than average. This provides some foundation for concluding that important spillovers exist in entrepreneurship. Yet the authors estimate that VC financing accounted for less than $10 \%$ of the differences in growth and activity across U.S. cities. These magnitudes are quite reasonable given the relative size of the VC industry.

The impact of VC financing can be seen as suggesting a role for credit-related policies, but there are profound questions about whether such policies are beneficial. First, it is possible to argue that the endogeneity of VC financing makes causal inference difficult. Second, it seems quite possible that direct public attempts at mimicking VC finance will be far less successful in 
picking winners than VCs themselves, especially if public sector choices are colored by noneconomic influences. Finally, even if the public sector supports VC in a more general way, with beneficial tax treatment for private VCs, for example, rather than engaging in direct lending itself, that support has costs and those costs may offset any benefits. If the government needs to raise sales taxes to offset the VC subsidies, this could easily do more harm than good. ${ }^{1}$

In a more recent paper, Glaeser et al. (2012) examine the broader question of entrepreneurship's impact on growth. Returning to the empirical relationships evident in Figure 1 , the authors implement an instrumental variable analysis that uses the extent to which cities were built near historical mines, especially with respect to coal and iron deposits, as predictors of their modern levels of entrepreneurship. The logic of this approach follows upon the observations of Chinitz (1961), who noted the role of mineral access in shaping the industrial origins of cities (e.g., Pittsburgh's strong start in the iron and steel industry was due to its proximity to coal mines). Even after these initial industries fade in importance, the initial conditions could have long-lasting effects on the traits of the cities going forward (e.g., due to children's aspirations and the city's attitudes towards entrepreneurship).

With this approach, Glaeser et al. (2012) continue to find that entrepreneurship was a key driver of U.S. city employment growth since the 1970s. The paper further dissects the industries in which the growth was occurring and the dynamic nature of this growth. Among the more interesting findings is that cities with strong foundations in entrepreneurship were not growing faster through the endless replication of small businesses. Instead, much of the employment growth in these cities was ultimately retained in establishments that became large employers. The cities thus possessed a more dynamic industrial structure that pushed firms through an up-orout process that generated more rapid urban growth. ${ }^{2}$

\footnotetext{
${ }^{1}$ Effective policy also needs to consider the marginal entrepreneur that will be induced to enter (de Maza 2002). In a study of the state-level banking deregulations that began in the 1970s, Kerr and Nanda (2009) find a very strong entrepreneurship response to greater banking competition in the local area. Some of these new firms grew to a size to challenge incumbents. This work also demonstrated, however, that a large number of the induced entrants were short-lived and failed within the first few years, typical of many entrepreneurial endeavors. This process of weeding out many failures to find the best entrants explains why policies often have a much larger effect on the entry margin than they do on general margins like economic growth.

${ }^{2}$ The outcomes of these assessments of entrepreneurship and entrepreneurial finance in the local area have been quite consistent with studies that have assessed firm-level consequences. Examples include Haltiwanger et al. (2012), Hurst and Pugsley (2012), Puri and Zarutskie (2012), Nandy et al. (2012), and Kerr et al. (2013). Fritsch and Wyrwich (2012) and Gutberlet (2013) have observed similar conditions in Germany to the Glaeser et al. (2012) study. Klapper et al. (2010) and Schoar (2009) discuss evidence from developing countries. Akcigit and Kerr (2010) provide evidence on the broader growth spillovers from entrepreneurial innovations.
} 
But this work also has few direct policy implications. It is not as if proximity to mines is a current policy variable, and presumably, over the long haul, these mines yielded plenty of local economic benefits as well. Perhaps the strongest suggestion generated by this work is that directly subsidizing large-scale manufacturing employers can be dangerous if those employers crowd out local entrepreneurship. However, given the benefits that Greenstone et al. (2010) have found from winning competitions for million-dollar plants, it seems sensible to be cautious about even this modest conclusion.

Moving from entrepreneurship to innovation, much of the recent work on the link between innovation and city performance has focused on a theoretical model developed by Duranton (2007). This model features prominently in explanations in urban economics of why cities grow or shrink and the movement of industries across cities. The premise of the model is that the location of industries in cities is determined by where past breakthrough inventions occurred. For example, Boston will be home to the mousetrap industry while Boston is the site of the latest frontier of mousetrap inventions, but should a better mousetrap be invented in Memphis, the model predicts that the industry would migrate from Boston to Memphis. This conceptual model produces patterns that line up well with the data: for example, it predicts that industries will move across cities much more rapidly than cities will move up and down the city size distribution.

While case studies of this process exist, the heart of the model's link to breakthrough inventions has been rarely tested. And there are plausible reasons why one might be skepticalwhy move a whole industry to a new location instead of just moving the invention itself? Some work on this topic predates the Duranton (2007) model. For example, Zucker et al. (1998) describe the exceptional embodiment of human capital in specialized workers in the emergence of the U.S. biotech industry. Much of the early development of the biotech industry occurred in cities that were home to the nascent industry's star scientists, rather than in places with lots of potentially related factors like VC funding, universities, etc. Audretsch and Feldman (1996) provide related evidence with the clustering of $\mathrm{R} \& \mathrm{D}$ industries.

To more generally assess the model's validity, Kerr (2010a) identifies the spatial location of the top $1 \%$ of new patents in 36 patenting technologies during 1975-1984. The study then compares the subsequent patenting growth in these locations for the ten cities with the highest relative concentration of these top patents to the next ten cities for the technology. Figure 3 is reproduced from this study. During the 1975-1984 period, these groups of cities looked quite similar to each other with the exception of the degree to which they experienced breakthrough inventions. However, over the next 20 years, the patenting growth was $20 \%$ higher in the group of cities with the largest share of breakthrough patent inventions. This confirms that the Duranton (2007) framework provides a good foundation for considering the dynamic evolution of cities. Kerr (2010a) also demonstrates the important role of immigrants for industry relocation 
(e.g., the rapid shift of semiconductors from Boston to Silicon Valley, the rapid rise of Micron in Boise, Idaho).

Beyond this development of breakthrough patents and new industry formation, there has been limited work on factors that promote overall innovation rates and employment growth of local areas. Agrawal et al. (2010) consider the traits of innovation in "company towns" that are dominated by one large firm. Their work finds that these large firms often become insular in their innovation, drawing more on the past experiences of the company and being less explorative in their R\&D efforts. Building on this study and earlier work on the anchor tenant hypothesis, Agrawal et al. (2012) consider what mix of large and small firms provides the most productive environment for innovation. The study finds that an optimal mix for patenting growth in a local area involves at least one large innovative firm but also a sufficient mass of many small innovative firms. This mix best captures the benefits of innovation that come out of large firms while maintaining fertile soil for new start-up companies, often founded by former employees of incumbent firms (e.g., Gompers et al. 2005, Chatterji 2009).

Universities can also be important anchor tenants for regional clusters. Hausman (2012) examines the role of universities in local areas. This study examines the extent to which U.S. universities stimulate nearby economic activity, using the passage of the Bayh-Dole Act in 1980 for identification. Long-run employment and wages increased quickly after Bayh-Dole in industries more closely related to local universities' pre-existing strengths in innovation. This effect was realized through the entrance of new firms and, especially, the expansion of multi-unit firms into the area. The power of local universities to engender economic growth is also studied by Moretti (2004) and Glaeser and Saiz (2004). These studies seem to support a limited policy conclusion favoring education. Again, however, costs must be weighed against benefits. Hausman's work seems most directly relevant to the question of whether to allow the commercialization of publicly-funded research, which does seem to have created sizable local economic benefits.

Despite the quite long tradition of researchers working with patent data, there has been relatively little work beyond these studies in the U.S. context that credibly identifies the role of local innovation in local employment growth. The existing body of work clearly highlights the importance of multiple actors in facilitating this link between innovation and regional prosperity (e.g., universities, R\&D labs in large firms, start-ups). This finding, along with case studies of the origin and rise of innovation regions (e.g., Kenney 2000, Lee and Nicholas 2012) suggest that the regional foundation for growth-enabling innovation is complex and that we should be cautious of single policy solutions that claim to fit all needs.

The existing work on entrepreneurship and local innovation does not imply any natural local policy. It does, however, point to the power of small start-ups, which can collectively shape 
the economic destiny of a locale. Seattle and Detroit were both dominated by large local manufacturers in the 1960s, and the big firms in both cities (Boeing, General Motors, etc.) showed subsequent employment declines. Seattle today, however, is thriving, unlike Detroit, because of a spate of local entrepreneurs, some of whom grew up in the city (such as Bill Gates) and others of whom were attracted to the city from outside (such as Jeff Bezos). A key question for local innovation policy is whether there is anything that can be done to inculcate more of that local entrepreneurship. Clusters are seen as a tool for advancing that goal, and we turn to the empirical evidence on economic clustering next.

\section{Spatial Concentration for Entrepreneurship and Innovation}

As discussed in Section 2, the case for cluster policies depends on the existence of strong cross-firm spillovers that generate clusters naturally and justify spatially-oriented entrepreneurship policies. For these policies to make sense, these spillovers must display increasing returns to scale (i.e., 200 entrepreneurs generate more than double the spillovers of 100 entrepreneurs) or accrue disproportionately to members of a particular industrial sector. That is, even if entrepreneurs generate spillovers, it only makes sense to cluster those entrepreneurs if those spillovers either work non-linearly in local areas or if only entrepreneurs benefit from the clustering with each other. We first outline a few descriptive facts about the spatial concentration of entrepreneurship and innovation in the United States. We do not spend too much time on this as this general feature of the economic landscape is well-known and not in much debate.

A starting point is the observation that industry itself is quite concentrated, even before considerations related to entrepreneurship and innovation. High-profile examples like entertainment in Hollywood and automobile manufacturing in Detroit are well-known, and the pattern extends more deeply. Ellison and Glaeser (1997) design a metric to estimate the degree to which an industry is more spatially concentrated than the general population. They find that 446 out of 459 manufacturing industries were more spatially concentrated than would be generally expected based upon underlying population. ${ }^{3}$ They also emphasize, however, that this clustering can represent either spillovers across firms or an uneven distribution of productive factors across space.

${ }^{3}$ Using a second technique developed by Duranton and Overman (2005), Kerr and Kominers (2010) calculate that over two-thirds of U.S. industries, within and outside of manufacturing, are spatially concentrated. Spatial concentration has been a key topic in economic geography since at least Marshall (1920). Ciccone and Hall (1996) provide an early link between this concentration and productivity. Duranton and Puga (2004) and Rosenthal and Strange (2004) review the theoretical and empirical literatures, respectively. 
Beyond this baseline, however, is the additional factor that some key aspects of entrepreneurship and innovation are even more spatially concentrated than general industry. This is particularly true for VC-backed entrepreneurship, as shown in Figure 4. Silicon Valley accounts for $40 \%$ of the total funding in 2011, with Boston and New York accounting for about $10 \%$ each. This is despite the fact that these cities together account for only about $11 \%$ of the U.S. population. Figure 5 similarly compares the distribution of VC investments, patents, and population across U.S. cities during the 1990-2005 period, showing that patenting is also spatially concentrated. ${ }^{4}$ But just as the geographic concentration of industry can reflect uneven natural advantage, the geographic clustering of industry may represent forces beyond spillovers, like a fondness for living in New York or San Francisco or the location of top research universities. Differences across places are naturally less when measuring all entrepreneurship, rather than focusing on high-growth entry. Nevertheless, the horizontal axes in Figure 1 highlight that entry rates differ quite substantially across U.S. cities.

Does this natural clustering make the case for policies that artificially induce clustering? Despite our caveats about clustering due to natural advantages being empirically difficult to distinguish from clustering due to economic interactions among firms ${ }^{5}$, there does seem at least the possibility that there are significant spillovers across entrepreneurs. It is possible, at least, that the government can help in coordinating these placements through cluster policy. Yet if the public role is primarily coordination, then this should require relatively minimal financial outlays. After all, if entrepreneurs benefit from coordination, they should come together of their own accord. In principle, this function of clustering entrepreneurs can also be performed by private developers, which is essentially the role played by Fred Terman in founding the Stanford Industrial Park. A recent example of this is the Cambridge Innovation Center in Kendall Square of Cambridge, MA, that co-locates 450 start-ups in a single building.

A large question in cluster policy is the relative benefits of industrial homogeneity within the cluster. Certainly, entrepreneurs in the same industry will often have the most to share. Yet there is also evidence for important intellectual spillovers across industries, and some of the most important breakthroughs reflect leaps from one industry to another. Michael Bloomberg, for example, succeeded in information technology precisely because he was not in Silicon Valley, but rather in New York City, and better understood what New York traders needed. While there

\footnotetext{
${ }^{4}$ See Carlino et al. (2007), Kerr and Kominers (2010), Carlino et al. (2012), and Murata et al. (2012) for further work on the spatial concentration of patenting in the United States.

${ }^{5}$ In a study of U.S. manufacturing, Ellison et al. (2010) find that clustering due to natural advantages of places is more important than any single form of economic spillovers among firms, but the collective weight of cross-firm interactions is more important than the natural advantages component. Kerr and Kominers (2010) provide some theoretical conditions where the two forms of clustering can be distinguished from each other.
} 
is little rigorous evidence on the causal impacts of industrial diversity, there is at least some correlational evidence suggesting that industrial monocultures do poorly (Glaeser et al. 1992) and some coarse evidence that technological diversity is associated with greater R\&D spending (Cohen and Malerba 2001). Perhaps those downsides are mitigated if a single industry cluster is located within a metropolitan area that is otherwise industrially diverse.

A final critical question regarding clusters and cluster policy is the role of infrastructure. Some industries require specialized infrastructure, including physical highways and information highways. Governments have long taken on the role of supporting infrastructure provision, even though economists since Smith have discussed the virtues of user fee financing. The need for specialized infrastructure does increase the value of clustering. By contrast, industrial groups with little need for specific government-provided technology will have fewer benefits from clustering.

\section{Spatial Determinants of Entrepreneurship and Innovation Clusters}

Even if clusters of entrepreneurship are good for local growth, it is less clear that cities or states have the ability to generate those clusters. We now describe studies of spatial factors that relate to entrepreneurship and innovation, and we consider what empirically attracts entrepreneurs to specific areas. Unlike the sparse literature reviewed in Section 3 on the economic consequences of entrepreneurship and innovation, the literature on local factors that generate or support clusters is quite broad, with research having been conducted in many countries and crossing multiple academic disciplinary boundaries (e.g., Acs and Armington 2006, Parker 2009). Space constraints do not allow us to mention every study. Instead, we review here some of the major themes emerging from this literature, and we attempt to highlight a few recent studies that provide special evidence.

\section{General Traits of Cities}

Among the general traits of cities that matter for entrepreneurship and innovation, three factors stand out most in the recent literature. First, the general education of the workforce has been linked to higher entry rates (e.g., Doms et al. 2010, Glaeser et al. 2010). This link is part of a larger finding in the urban literature that local human-capital levels are important to the development and growth of areas (e.g., Simon 1998, Simon and Nardinelli 2002, Glaeser and Saiz 2004, Gennaioli et al. 2012). However, within the manufacturing sector, Glaeser and Kerr (2009) do not find a city's education level to be important for entrepreneurship, so this connection appears to depend somewhat on the sector. 
A second factor that is often found to be important is the age structure of the local area. Here, however, much depends upon the metric used to measure entrepreneurship, a subject discussed in greater detail in Glaeser and Kerr (2009). Studies that utilize self-employment status (e.g., Evans and Jovanovic 1989) to measure entrepreneurship often find older workers to be conducive to higher entry, due to the greater weight placed on small-scale, independent operators. This can be most easily seen in self-employment rankings that list West Palm Beach, FL, as America's most entrepreneurial city but place San Jose, CA, near the bottom. On the other hand, studies employing metrics that emphasize the creation of start-ups that employ other workers tend to find workers in ages near 40 years old to be most important (e.g., Bönte et al. 2009, Glaeser and Kerr 2009).

The final, and perhaps the most surprising finding, is the importance of the "local supply" of entrepreneurs. This factor has an odd ring to it, as we tend to think of entrepreneurs as rapidly responding to new opportunities and not confined to one location. While this mobility is certainly true at the very high end of start-ups, with entrepreneurs from around the world flocking to Silicon Valley, a strong and growing literature points out that regions may differ in the extent to which their general population is inclined towards entrepreneurship. Several studies have documented that entrepreneurs tend to disproportionately found their companies in their regions of birth (e.g., Figueiredo et al. 2002, Michelacci and Silva 2007, Audretsch et al. 2012), and that these business are in fact stronger on average than the businesses of the typical migrating entrepreneur. This strength of place undergirds the arguments put forth in Glaeser et al. (2012) on why the Chinitz effect and industrial origins of cities would persist over time to affect recent entrepreneurship. This fact is not easy to reconcile in standard urban economic models that assume a spatial equilibrium holds through rapid mobility of workers and firms, but the empirical fact is quite robust to alternative analyses (e.g., Glaeser et al. 2010). This line of work suggests that policy efforts to build entrepreneurship among a location's existing residents may be more powerful than efforts to attract outside entrepreneurs to the city.

Beyond these factors, we make the simple observation that more must be learned about the role of local physical infrastructure (e.g., roads, broadband internet access). The prior section noted the links between infrastructure and clusters. A variety of studies from developing economies stress the importance of these factors, but evidence using variation across regions in the United States is less common. These studies would constitute an important input for policy makers, since entrepreneurial cluster projects are often launched as part of downtown revitalization projects and paired with investments in connectivity (e.g., the Google Fiber project in Kansas City). 


\section{Industry-Level Clustering}

Turning to industry-level entry rates in cities, studies consistently find the most powerful predictor of future entrepreneurship for a city-industry to be the presence and strength of incumbent firms in the city-industry (e.g., Figueiredo et al. 2009). For a typical estimate in this regard, Glaeser and Kerr (2009) estimate that a 10\% higher base of incumbent firms is associated with a $6 \%$ higher number of start-ups in the city-industry. For U.S. manufacturing, the existing business landscape explains about $80 \%$ of the spatial variation in new entry rates.

This persistence is not too surprising for two reasons. First, many entrepreneurs leave incumbent firms to start their companies. Klepper (2010) shows in detail the importance of this spawning process in the history of Detroit and Silicon Valley. Gompers et al. (2005) find the spin-off process especially important among entrepreneurial high-tech firms, leading to persistence in local technology clusters. Second, given the high degree to which start-up companies draw resources from their local area and knowledge from incumbent firms, with former employees as a frequent conduit (Chatterji 2009), it is not surprising that they are attracted to places that have proven hospitable for the industry in the past.

While the older literature on this latter point is mostly anecdotal, research over the last five years has developed sharper techniques for quantifying how the broader industrial composition of a city relates to entrepreneurship for a particular industry. A methodological advance in this regard uses the lens of the traditional agglomeration rationales first defined by Marshall (1920): access to customers and suppliers, access to required labor inputs, and access to ideas or technology. Recent studies first develop metrics of how related industries are to each other across these dimensions (e.g., input-output tables, occupational similarity). The second step then combines micro data on industrial distribution within a city with these metrics of industry relatedness. This approach effectively consolidates data on hundreds of industries into a small number of easily interpreted traits about how amenable to entrepreneurship a local area is in terms of factors like access to customers, access to labor, etc.

Glaeser and Kerr (2009) first apply this approach to the United States using the indices developed in Ellison et al. (2010). The approach has also been used to describe spatial entrepreneurship rates and city structures in other countries (e.g., Jofre-Monseny et al. 2011, Dauth 2011, Ghani et al. 2011, Mukim 2011). The strongest conclusions from this body of work emphasize the importance of labor inputs for start-up firms and the Chinitz effect. Local industrial structures that contain the types of workers most needed by an industry have significantly higher entrepreneurship levels. Combes and Duranton (2006) also emphasize this suitability of the local labor force. Local industrial structures with smaller firms in supplier industries for a given industry also have higher entry rates. 
A final feature is the strong reliance on immigrants for the U.S. science and engineering (SE) workforce (e.g., Stephan and Levin 2001). We group this under industry-level clustering given its particular importance for technology sectors. Immigrants represented $24 \%$ and $47 \%$ of the U.S. SE workforce with bachelor's and doctorate educations in the 2000 Census, respectively. This contribution was significantly higher than the $12 \%$ share of immigrants in the U.S. working population. Moreover, Kerr and Lincoln (2010) estimate that immigrant scientists and engineers account for more than half of the net increase in the U.S. SE labor force since 1995. Immigrant entrepreneurs are also significantly involved in the development of start-ups to pursue the commercialization of new technologies. Immigrant founders account for a substantial share of Silicon Valley's start-ups, for example.

U.S. cities and states differ strongly in the extent to which they rely on immigrant scientists and entrepreneurs. As one example, Kerr and Lincoln (2010) estimate that the mostdependent cities, such as San Francisco, are twice as reliant on immigrant scientists and engineers as the $10^{\text {th }}$ most dependent cities, such as Atlanta or Dallas. The consequence of this dependency is that immigration policy can create supply shocks across areas in the innovation workforces (e.g., Kerr and Lincoln 2010, Hunt and Gauthier-Loiselle 2010). While the United States was on a long-term trend for patenting to become more distributed spatially, Kerr (2010b) describes how the spatial concentration of immigrants and their growing importance for U.S. innovation has reversed the trend, leading to more spatially concentrated innovation.

\section{A City is Full of Different People and Places...}

Our discussion so far has viewed clusters and industries as homogeneous units, and yet the San Francisco Bay Area has many types of people - differences by gender, education, race and ethnicity, etc. - and the metropolitan area is comprised of many unique places. Palo Alto is quite different from Oakland, and even neighborhoods within Palo Alto are quite distinct from each other. An emerging frontier in this literature is better defining who partakes of cluster benefits and who is excluded. This is important for policy design to the extent that the argument for promoting a local district, like the Boston Innovation District discussed earlier, is being made about broader benefits to the region.

Starting with types of entrepreneurs, Rosenthal and Strange (2012) consider the spatial sorting of male and female entrepreneurs within U.S. cities. The authors note that female entrepreneurs may benefit less from being in the core of an industrial cluster, to the extent that they have either weaker networking contacts than their male counterparts or face greater commuting costs (e.g., due to higher domestic responsibilities). The authors find empirical evidence that women-owned businesses are more segregated in local areas and that female 
entrepreneurs are exposed to $10-20 \%$ less of their own-industry employment. Looking at India, Ghani et al. (2013) find evidence in line with Rosenthal and Strange (2012) and further show it linked through the industrial structure framework reviewed in the prior sub-section. This recent work on the gender of entrepreneurs continues, more broadly, a longer literature on racial segregation in local areas. This specificity of local networks suggests that policy makers need to consider the extent to which various groups will benefit from a targeted intervention and whether inclusionary selection criteria are therefore warranted.

The second frontier of recent work focuses on a better understanding of places and spatial distances within cities. Since at least the work of Rosenthal and Strange (2003), it has been clear that spillovers can attenuate rapidly. Recent improvements in data allow much finer assessments, and Arzaghi and Henderson (2008) bring this issue to central focus through an analysis of advertising agencies in Manhattan. While prior work thought about cities as the aggregate level, or always measured distances in terms of miles, Arzaghi and Henderson (2008) find spillover benefits in Manhattan decay very rapidly over just a few city blocks. This work makes clear that future research needs to develop a better sense of how clusters are structured and how this structure governs spillover flows (e.g., Kerr and Kominers 2010). This feature will govern the extent to which an intervention like the Boston Innovation District also aids entrepreneurs in Cambridge's Kendall Square or even farther out of the city on Route 128. It would also provide insights into whether a waterfront site like the Boston Innovation District limits the potential for spillovers compared to a location that would have offices on all sides.

\section{Policies for Encouraging Entrepreneurial Clusters}

We now return to the questions raised in Section 2, using the evidence provided in the previous three sections. Instead of discussing the general classification of industrial and innovation policies, we turn to specific policies aimed at engendering local entrepreneurship. While these policies have proliferated recently (Acs et al. 2008, Furth 2012), there is a longer tradition in the United States, dating back to at least 1953, with the creation of the Small Business Administration (SBA), of supporting small businesses by increasing access to credit and opening up opportunities for government procurement. For our purposes, Haltiwanger et al. (2012) provide a useful delineation between small businesses and new businesses, which most often start small. The authors find that the job creation and associated benefits typically ascribed to small businesses are disproportionately provided by new start-ups. Thus, we apply this lens to our discussion and focus on policies that explicitly target start-ups.

In principle, the various public policies that could influence entrepreneurship span tax, education, immigration, technology and standards, financial markets, intellectual property, and 
several other policy domains. Moreover, entrepreneurship policies are often embedded in larger regional cluster initiatives and can emanate from federal, state, and local authorities. To provide a parsimonious but informative review of relevant policies, we focus our attention on initiatives targeted at supporting the founding and growth of start-ups in specific geographic regions.

Reflecting on Figure 2, we do not discuss general policies (e.g., intellectual property laws) or aid to specific companies. Furthermore, rather than providing a comprehensive list of state and local entrepreneurship policies, we highlight the general practices that underpin nearly all of these initiatives. We also discuss a notable shift in recent federal government policy towards actively promoting high-growth entrepreneurship in specific regions. As we are not aware of other work that compiles all of these different initiatives, we spend a bit more time in this section reviewing the origin of programs and their sponsors.

\section{Policies to Increase the "Local Supply" of Entrepreneurs}

As discussed above, entrepreneurship has a surprisingly local flavor in that entrepreneurs tend to disproportionately found firms near where they were born. In this spirit, policymakers have initiated several programs that seek to increase the supply of entrepreneurs in an area. These include entrepreneurial education programs, science and technology education initiatives, and high-skilled immigration policy. Entrepreneurship courses have proliferated at colleges and universities around the United States, and today approximately two-thirds of all institutions offer at least one course on entrepreneurship ${ }^{6}$, while 500 institutions offer a major, minor or certificate. $^{7}$

Federal government support for entrepreneurship education and training is funneled most directly through the SBA's Office of Entrepreneurship Education. In addition, there are smaller programs in the Department of Commerce and USDA to support entrepreneurship education, and the National Science Foundation (NSF) recently launched iCorps to provide mentorship and commercialization advice to their grant recipients. ${ }^{8}$ These programs are typically quite small. For example, the SBA's 2012 budget request for their SCORE counseling program, which matches retired executives and entrepreneurs with small businesses for free consulting and mentoring, was $\$ 7$ million. ${ }^{9}$ At the state level, 18 states have passed some legislation as of 2007 to

\footnotetext{
${ }^{6} \mathrm{http}: / /$ www.kauffman.org/entrepreneurship/teaching-entrepreneurship-in-colleges.aspx

${ }^{7}$ https://www.ida.org/upload/stpi/pdfs/d-4091nsfinal072910.pdf

${ }^{8}$ http://www.nsf.gov/news/special_reports/i-corps/index.jsp

${ }^{9}$ http://www.sba.gov/content/fiscal-year-2012-budget-summary
} 
encourage entrepreneurship education, with significant variance in terms of requirements and curriculum. $^{10}$

There is no systematic assessment of these entrepreneurship education programs that we are aware of. Assessments of these programs outside of the United States have been inconclusive, with some studies finding positive effects but just as many not seeing an impact. Moreover, it is not clear what the appropriate outcome of interest should be. One view of entrepreneurship education might be that its goal should be to produce more entrepreneurs. On the other hand, entrepreneurship education could also help students learn more about their own inclination towards entrepreneurship and chances of success, leading to better-informed career choices, but not necessarily more entrepreneurs.

Science, technology, engineering, and math (STEM) education policy is frequently paired with entrepreneurship initiatives. Since a disproportionate percentage of high-growth start-ups are in technical fields, policymakers have sought to increase the supply of technically skilled individuals through investments in teachers, facilities, scholarships and grants. As an example, the NSF recently provided a grant to North Carolina Central University to implement "DREAM STEM," a $\$ 1.75$ million program to identify scientists and integrate entrepreneurship into scientific education. ${ }^{11}$

Furthermore, high-skilled immigration policy is a key component of increasing the supply of entrepreneurs. While there is a large body of literature on high-skilled immigration and entrepreneurship, for the purposes of our review, the most relevant policies are those which seek to attract immigrant entrepreneurs to specific regions. While there exists no specific U.S. visa program for entrepreneurs, there have been proposals recently for a "Start-up Visa" for immigrant entrepreneurs who can attract investment from a qualified U.S. investor. ${ }^{12}$ This program draws heavily from the EB-5 visa program, enacted in 1990, which provides a path to permanent residency for foreign investors depending on the size of investment and the number of jobs created. Under a pilot program, some U.S. states and regions have created over 260 "Regional Centers" to attract EB-5 investors to their areas. If a Startup Visa program is ever enacted, it is possible that this "localization" dimension could also be developed. Absent these specific policies, local leaders can take simpler steps to make their cities more attractive to immigrants (e.g., educating local employers about visa programs, providing online information

${ }^{10}$ https://www.ida.org/upload/stpi/pdfs/d-4091nsfinal072910.pdf

${ }^{11}$ http://nccueagles.yuku.com/topic/7648/New-Program-Combines-STEM-Education-andEntrepreneurship\#.URwZmmdX98E

${ }^{12} \mathrm{http} / / / \mathrm{www} \cdot k e r r y . s e n a t e . g o v /$ press/release/?id=4e6a51f6-fb2b-4212-b299-b0c46c7e6b58 
about the city to immigrants), should they want to expand this input into their economy. Michael Bloomberg, for example, has been particularly vocal on skilled immigration topics and aggressive in his support of recruiting skilled immigrants to New York City.

Finally, other policies seek to increase the local supply of entrepreneurs by reducing the barriers to entry for particular groups. For example, as described by Chatterji et al. (2013), many U.S. cities set aside local government contracts during the 1980s for women and racial minorities in an effort to spur local entrepreneurship. The total cost of these programs is estimated to be several hundreds of billions of dollars, and Chatterji et al. (2013) find that city's set-aside programs significantly increased self-employment among African Americans and narrowed the black-white self-employment gap by three percentage points during the 1980s. Many race-based contracting programs were replaced by disadvantaged business programs following the 1989 Supreme Court Decision in Richmond v. Croson.

\section{Direct Subsidies and Targeted Tax Breaks to Promote Entrepreneurship}

Policymakers at all levels of government, particularly at the state level, are also actively providing more direct assistance to start-up firms. Several states have created programs to provide R\&D funds to local start-ups, sometimes in the form of loans or convertible debt. One of the rare rigorous evaluations of these state-level programs found that recipients in Michigan were $15-25 \%$ more likely to survive after three years relative to a set of comparable firms (Zhao and Ziedonis 2012). A serious question going forward is whether these programs also develop ventures that scale significantly in the local area.

Many states have also developed state VC funds that can operate through certified capital companies (CAPCOs) or related models. Lerner (2009) provides insights into why these kinds of programs often fail and offers several recommendations for best practices across these programs. Lerner's results suggest that the "setting the table" activities that governments can provide to create a stronger business environment for start-ups tend to be more successful than direct investments in firms. These programs have historically had numerous design flaws, leading to reduced flexibility for investors and entrepreneurs, adverse selection of investment managers, and limited upside with significant downside risk for the taxpayer. Other states and cities have tried to directly attract entrepreneurs to relocate by sponsoring incubators (e.g., New York City) or explicitly requested VC investors to visit the area and meet local entrepreneurs as a condition for state investment in a particular venture fund.

Finally, there have also been many efforts to create tax incentives for investments in start-ups in particular areas. For example, over 20 U.S. states have instituted tax credits for angel investors. Other states have established early-stage investment tax credits for investments in 
qualified start-ups. Despite the proliferation of these programs, we are not aware of robust evidence of their impact on early-stage investments. For example, it could be possible that these tax credits reduce government revenue without inducing new investments or increasing the number of companies that receive funding. These credits could also simply increase competition for deals and bid up valuations. ${ }^{13}$

\section{Regional Clusters Policies to Promote Entrepreneurship}

Next, we review policies that attempt to promote entrepreneurship as part of broader regional cluster efforts. Cluster policies have proliferating in the United States since at least 1990, following Porter (1990). Despite wide adoption at the regional, state, and local level, U.S. federal policy has paid little attention to clusters until very recently. ${ }^{14}$ Porter argues that regional cluster policy operates below "macro-level" polices to improve the general business environment for all firms through "setting the table" activities (Lerner 2009), and above "micro-level" policies that aid individual firms (Porter 2007). ${ }^{15}$

Silicon Valley, Boston's Route 128, and Research Triangle Park are three of the most well-known clusters in the United States and among those most often associated with entrepreneurship and innovation. However, the role of public policy in creating and sustaining these regions as attractive locations for entrepreneurship is complex. Interestingly, while Silicon Valley and Route 128 certainly benefited from federal research funds (Dorfman 1983), neither arose as a result of a cohesive federal vision and plan, perhaps with not even much intentionality from any level of government or academic institution. On the other hand, the Research Triangle Park in North Carolina was clearly a product of dedicated state-level planning, beginning with Gov. Luther Hodges in 1955 and continuing through successive administrations which worked to identify and attract private investors for the project (Link and Scott 2003). While the federally sponsored National Environmental Health Sciences Center was an early tenant in the park, the arrival of IBM in 1965 was much more pivotal (Link and Scott 2003). Taken together, while public policy played some role in the creation of the United States' most successful clusters, there was no national-level strategy to develop and sustain these clusters. Even after these

${ }^{13}$ http://www.businessweek.com/smallbiz/content/aug2010/sb20100820_461551.htm

${ }^{14}$ There have been several high profile place-based strategies to develop U.S. regions that lag behind economically, from the Reconstruction period after the Civil War to the New Deal programs of the 1940s to the Appalachian Regional Commission.

\footnotetext{
${ }^{15}$ Related work includes Furman et al. (2002), Duranton (2011), Kline and Moretti (2012), and Falck et al.
} (2012). 
clusters rose to prominence and were celebrated in the 1980s and 1990s, U.S. federal policy towards clusters was minimal and remained so until at least 2010.

Policies at the state and local level to build and support clusters typically involve a mix of initiatives depending on the stage of the development of the cluster. The first step in cluster development is to identify the candidate cluster by geography, industrial composition, and existing networks. Government funds can be awarded to do this initial study, or private organizations may commission this work to raise awareness and use in applications for government funding in the future.

Once a cluster is identified and recognized by government authorities, there are several approaches to build capacity within the cluster, some of which can be targeted at entrepreneurial start-ups. For example, a report from the OECD indicates that one common set of policies relates to building a pipeline between university research and start-up formation. ${ }^{16}$ These can include providing funds for joint research, encouraging the development of standardized licenses to facilitate technology transfer, or coordinating seed funding for university spinoffs. Broadly, regional cluster policy levers to encourage start-up formation and growth typically aim to spur knowledge transfer across various organizational boundaries, whether it be universities, incumbent firms, or other start-ups. Government funds are most often used to convene various organizations and facilitate networks, and less frequently directly invested into new firms. In light of the positive studies of university contributions noted earlier, efforts in this regard may yield decent returns.

\section{New Federal Focus on Promoting High-Growth Entrepreneurship in Clusters}

Since 2009, there has been much more emphasis on federal policies to promote highgrowth entrepreneurship in regional clusters. As of 2008, the federal government already had 250 overlapping programs worth $\$ 77$ billion that were designed in part to spur regional economies. ${ }^{17}$ However, these programs were generally not coordinated in any significant way. Over the past five years, the U.S. government has been much more active in trying to reorganize regional cluster efforts to be more efficient and have greater impact. The Obama Administration

\footnotetext{
${ }^{16}$ OECD, Competitive Regional Clusters: National Policy Approaches (OECD Reviews of Regional Innovation, 2007)

${ }^{17}$ Karen Mills, Elisabeth Reynolds, and Andrew Reamer, "Clusters and Competitiveness: A New Federal Role for Stimulating Regional Economies," Metropolitan Policy Program at Brookings, April 2008.
} 
has framed this shift as redeploying existing resources more strategically rather than allocating significant new funds. ${ }^{18}$

The hub for these efforts has been the Department of Commerce's Economic Development Agency (EDA), which was launched in 1965 to assist economically depressed urban and rural areas. EDA was allocated \$50 million in 2010 to support regional innovation clusters, and the America Competes Reauthorization of 2010 also called on the Secretary of Commerce "to establish a regional innovation program to encourage and support the development of regional innovation strategies, including regional innovation clusters and science and research parks."19

While Commerce's EDA continues to play a pivotal role, beginning with the 2011 budget, the Obama Administration has included several different agencies in its regional clusters strategy. ${ }^{20}$ The largest investment in clusters to date is a $\$ 129$ million investment over five years in the Energy Regional Innovation Cluster in Philadelphia, involving many parts of the federal government. Nearly all of the funds (\$122 million) will come from the Department of Energy’s Energy Innovation Hubs, program which was funded through the Recovery Act. ${ }^{21}$ The other agencies are providing either small amounts of funding or technical assistance from existing programs, such as the Department of Labor's One-Stop Career Centers. As is typical with regional cluster policies, the recipient of the funding and technical assistance is a consortium of academic institutions, government bodies, and regional development groups called the Greater Philadelphia Innovation Cluster.

In addition to this large investment, there have been two other regional innovation cluster investments worth several million dollars in total in Florida (Space Shuttle Shutdown Transition) and Ohio (Water Technology Innovation Cluster). ${ }^{22}$ Finally, the SBA also invested \$1 million each in 10 pilot clusters in 2010, three of which focused on Advanced Defense Technologies. ${ }^{23}$ Another key clusters initiative, launched in September 2011, was the \$37 million Jobs and

\footnotetext{
${ }^{18}$ The Empowerment Zones program, discussed earlier, expired at the end of 2011.

${ }^{19}$ America COMPETES Reauthorization Act of 2010 (http://thomas.loc.gov/cgibin/bdquery/z?d111:HR05116:@@@\&summ2=m\&)

${ }^{20} \mathrm{http}: / / w w w . n e w r e p u b l i c . c o m / b l o g / t h e-a v e n u e / b u d g e t-2011$-industry-clusters-paradigm-job-growth

${ }^{21} \mathrm{http}: / /$ scienceprogress.org/2010/08/a-win-for-regional-innovation/

${ }^{22}$ http://www.sba.gov/cluster; http://billnelson.senate.gov/news/details.cfm?id=334172\&; http://yosemite.epa.gov/opa/admpress.nsf/0/5C6E98E36238C0898525781C005B7B73

${ }^{23}$ http://www.entrepreneur.com/slideshow/225398
} 
Innovation Accelerator Challenge sponsored by the SBA, Commerce and Labor which supported 20 clusters. The Department of Labor provided \$19.5 million for technical skill development, Commerce's EDA provided $\$ 14.5$ million for economic adjustment assistance, and the SBA added $\$ 3$ million in technical assistance. The winning clusters provided matching funds of $\$ 13$ million.

Two later stages of this initiative were the Rural Jobs and Innovation Accelerator Challenge, launched in March 2012 with \$15 million of funding, and the 3rd Jobs and Innovation Accelerator Challenge, which began in May 2012 with \$20 million focused on advanced manufacturing. Each of these rounds involved a competitive grant application and an emphasis on public-private partnerships. Most of the clusters funded by these grants existed formally or informally before receiving funding. The participation of the SBA in these initiatives is specifically designed to increase opportunities for small businesses in the clusters by leveraging specific SBA services, such as those provided by Small Business Development Centers (SBDCs).

In sum, as of April 2012, the Obama Administration has spent over \$225 million on regional cluster projects and requested another $\$ 25$ million in the 2013 budget. $^{24}$ This is a small amount of money in the context of the overall budget but is consistent with an emphasis on reorganizing existing funding streams more strategically to support clusters.

\section{Other Relevant Federal Efforts to Promote High-Growth Entrepreneurship}

Other recent federal initiatives fall under the broad category of "setting the table" for high-growth entrepreneurship. One of the highest-profile Obama Administration efforts was "Startup America," an umbrella initiative encompassing several related efforts to promote highgrowth entrepreneurship. It includes proposals to increase access to capital, enhance entrepreneurial education and mentorship, limit regulatory barriers to starting and growing companies, spur technology commercialization efforts from universities, and open up entrepreneurial opportunities in key industries like healthcare, energy and education. Various parts of the Startup America agenda have been enacted through legislation, while other parts have not required legislative approval and have been implemented by the relevant agencies.

Some key components of the Startup America policy agenda were passed in the 2011 JOBS Act (Jumpstarting our Business Startups). The focus of the JOBS Act was on reducing the

\footnotetext{
${ }^{24}$ http://www.politifact.com/truth-o-meter/promises/obameter/promise/309/support-regional-innovationclusters/
} 
financial reporting requirements for small firms and facilitating crowd funding, making it easier for individuals to invest in or contribute funds to start-ups. It raised the limit of Regulation A securities offerings to $\$ 50$ million, lifted the ban on general solicitation, and created a new class of companies - called emerging growth companies - that will have fewer disclosure requirements.

The federal government has also taken other lower profile steps, under the banner of Startup America, to explicitly to promote high-growth entrepreneurship. The Obama Administration modified the Small Business Investment Company program to offer two new \$1 billion funds to invest in high-growth businesses. Several government agencies, including the SBA, Veterans Affairs, and the Department of Energy have sponsored business accelerators. The USPTO also announced a new fast track 12-month patent application process that is especially targeted at entrepreneurial firms. The National Institutes of Health have simplified the process to license technologies for biomedical start-ups.

\section{Conclusions}

Even though entrepreneurship is a powerful force that engenders local and economic growth, it is not obvious that government policy can create entrepreneurship. Even if entrepreneurs naturally cluster in tight geographic units, it is not obvious that the government should use public policy to support such clusters. While the entrepreneurship policies discussed above generally do not require large funding streams, it is still important to consider the downsides of ineffective policies. At this point, we are still just beginning to acquire enough wisdom to create sound policies that internalize the externalities that can come from innovation and new start-ups.

While we believe that there are conclusions that can be drawn at this stage-research universities powerfully impact local development; focusing on large-scale employers can crowd out small scale start-ups — we need much more information before entrepreneurship policy can attain the relatively mature status enjoyed by, for example, policies towards international trade and monopoly. The primary need is for experimentation and evaluation, especially with randomization. For example, if a government is creating an entrepreneurial cluster that is oversubscribed, it can randomize at least some of the spaces in the cluster. By comparing the outcomes of winners and losers in the "space lottery," the government can evaluate the impact of the policy. If the government continues providing loan guarantees on a firm-by-firm basis, at least some of the loans can be randomly allocated in a way that permits ex post evaluation of the impact of those loans. 
Experimentation is happening all across the nation today, as government at all levels (along with numerous private and non-profit organizations) craft policies in the hopes of creating "the next Silicon Valley." The problem is that this experimentation is almost entirely ad-hoc and often it is unclear what outcome variables (i.e., number of start-ups, employment, patents) should be measured. Moreover, most policymakers, especially when programs are relatively inexpensive, might naturally favor the "kitchen sink" approach whereby every potential intervention that could increase entrepreneurship is tried simultaneously. In fact, efforts to provide entrepreneurial education, access to capital, export promotion, and the like in a concentrated region are often favorably billed as a "one-stop shop" for start-ups, which makes evaluation of any single policy intervention challenging.

Evaluation as a concept is becoming more important to regional cluster initiatives, in particular, as well as other programs that promote entrepreneurship. The key challenge here is that plausible counterfactuals against which benchmark performance is measured are difficult to construct and thus rarely considered, making interpretation of any results very difficult. Relatedly, the use of randomization to create research opportunities is especially complex in this domain, where policymakers often intentionally target specific areas for additional funding and where "winners and losers" are highly visible.

While the obstacles to creating better research designs to study these programs are formidable, they are not impossible to overcome. Many agencies, including the SBA, already submit evaluations of certain programs to Congress along with their budget requests. It should be possible to provide broad outlines of what a good evaluation should look like, and Congress could provide guidance informed by academics in this regard. Moreover, given the U.S. government's newly prominent role in promoting high-growth entrepreneurship and regional clusters specifically, the federal grant competitions could be designed to reward rigorous evaluations and specific milestones achieved.

It would be ideal to conclude that paths towards better entrepreneurship policies are clear, but they are not. Some policies do seem to have many upsides and few downsides, such as allowing more skilled immigrants, strengthening education systems, and eliminating unwise regulations. But when we move beyond such simple broad policies towards specific entrepreneurship strategies like clustering, our ignorance becomes obvious. The best path forward involves experimentation and evaluation. Without advances in these dimensions, we cannot be confident that policies to promote entrepreneurship will have their intended impact. 


\section{References}

Acs, Zoltan, and Catherine Armington, Entrepreneurship, Geography and American Economic Growth (New York, NY: Cambridge University Press, 2006).

Acs, Zoltan, Edward Glaeser, Robert E. Litan, Lee Fleming, Stephan J. Goetz, William Kerr, Steven Klepper, Stuart Rosenthal, Olav Sorenson, and William Strange, "Entrepreneurship and Urban Success: Toward a Policy Consensus", Kauffman Foundation Research Report (2008).

Agrawal, Ajay, Iain Cockburn, Alberto Galasso, and Alexander Oettl, "Why are Some Regions More Innovative than Others? The Role of Firm Size Diversity", NBER Working Paper 17793 (2012).

Agrawal, Ajay, Iain Cockburn, and Carlos Rosell, "Not Invented Here? Innovation in Company Towns", Journal of Urban Economics 67:1 (2010), 78-89.

Akcigit, Ufuk, and William Kerr, “Growth Through Heterogeneous Innovations”, Working Paper (2010).

Arzaghi, Mohammad, and J. Vernon Henderson, "Networking off Madison Avenue", Review of Economic Studies 75:4 (2008), 1011-1038.

Audretsch, David, Oliver Falck, Maryann Feldman, and Stephan Heblich, "Local Entrepreneurship in Context", Regional Studies 46:3 (2012), 379-389.

Audretsch, David, and Maryann Feldman, "R\&D Spillovers and the Geography of Innovation and Production", American Economic Review 86 (1996), 630-640.

Boekholt, Patries, and Ben Thuriaux, "Public Policies to Facilitate Clusters: Background, Rationale and Policy Practices in International Perspective”, Boosting Innovation: The Cluster Approach (1999), 381-412.

Bönte, Werner, Oliver Falck, and Stephan Heblich, "The Impact of Regional Age Structure on Entrepreneurship", Economic Geography 85 (2009), 269-287.

Busso, Matias, Jesse Gregory, and Patrick Kline, “Assessing the Incidence and Efficiency of a Prominent Place Based Policy", American Economic Review (2013), forthcoming.

Carlino, Gerald, Jake Carr, Robert Hunt, and Tony Smith, "The Agglomeration of R\&D Labs", Working Paper (2012).

Carlino, Gerald, Satyajit Chatterjee, and Robert Hunt, "Urban Density and the Rate of Invention", Journal of Urban Economics 61 (2007), 389-419.

Chatterji, Aaron, "Spawned with a Silver Spoon?: Entrepreneurial Performance and Innovation in the Medical Device Industry”, Strategic Management Journal 30 (2009), 185-206.

Chatterji, Aaron, Kenneth Chay, and Robert Fairlie, "The Impact of City Contracting Set-Asides on Black SelfEmployment and Employment", Journal of Labor Economics (2013), forthcoming

Chatterji, Aaron, and Robert Seamans, "Entrepreneurial Finance, Credit Cards and Race", Journal of Financial Economics, 106:1 (2012), 182-195.

Chemmanur, Thomas, Karthik Krishnan, and Debarshi Nandy, "How Does Venture Capital Financing Improve Efficiency in Private Firms? A Look Beneath the Surface”, Review of Financial Studies 24:12 (2011), 4037-4090.

Chinitz, Benjamin, "Contrasts in Agglomeration: New York and Pittsburgh", American Economic Review 51:2 (1961), 279-289.

Ciccone, Antonio, and Robert Hall, "Productivity and the Density of Economic Activity", American Economic Review 86:1 (1996), 54-70.

Cohen, Wes, and Franco Malerba, "Is the Tendency to Variation a Chief Cause of Progress?", Journal of Industrial and Corporate Change 10 (2001), 587-608.

Combes, Pierre-Philippe, and Gilles Duranton, "Labour Pooling, Labour Poaching, and Spatial Clustering", Regional Science and Urban Economics 36 (2006), 1-28.

Dauth, Wolfgang, "The Mysteries of the Trade: Interindustry Spillovers in Cities", Working Paper (2011).

de Meza, David, “Overlending?” Economic Journal 112:477 (2002), F17-F31. 
Delgado, Mercedes, Michael Porter, and Scott Stern, "Clusters and Entrepreneurship", Journal of Economic Geography 10:4 (2010a), 495-518.

Delgado, Mercedes, Michael Porter, and Scott Stern, "Clusters, Convergence and Economic Performance", CES Working Paper 10-34 (2010b).

Doms, Mark, Ethan Lewis, and Alicia Robb, "Local Labor Force Education, New Business Characteristics, and Firm Performance", Journal of Urban Economics 67:1 (2010).

Dorfman, Nancy, "Route 128: The Development of a Regional High Technology Economy", Research Policy 12:6 (1983), 299-316.

Duranton, Gilles, "Urban Evolutions: The Fast, the Slow, and the Still", American Economic Review 97:1 (2007), 197-221.

Duranton, Gilles, “California Dreamin': The Feeble Case for Cluster Policies”, Review of Economic Analysis 3 (2011), 3-45.

Duranton, Gilles, and Henry Overman, "Testing for Localization Using Micro-Geographic Data", Review of Economic Studies 72 (2005), 1077-1106.

Duranton, Gilles, and Diego Puga, "Micro-Foundations of Urban Agglomeration Economies", in Vernon Henderson and Jacques François Thisse (eds.) Handbook of Regional and Urban Economics, Volume 4 (Amsterdam: North-Holland, 2004), 2063-2117.

Ellison, Glenn, and Edward Glaeser, "Geographic Concentration in U.S. Manufacturing Industries: A Dartboard Approach", Journal of Political Economy 105 (1997), 889-927.

Ellison, Glenn, Edward Glaeser, and William Kerr, "What Causes Industry Agglomeration? Evidence from Coagglomeration Patterns", American Economic Review 100 (2010), 1195-1213.

Evans, David, and Linda Leighton, "Some Empirical Aspects of Entrepreneurship", American Economic Review 79 (1989), 519-535.

Falck, Oliver, Michael Fritsch, and Stephan Heblich, "Bohemians, Human Capital, and Regional Economic Growth", Jena Economic Research Papers 2009-049 (2009).

Falck, Oliver, Christina Guenther, Stephan Heblich, and William Kerr, "From Russia with Love: The Impact of Relocated Firms on Incumbent Survival”, Journal of Economic Geography (2013), forthcoming.

Fallick, Bruce, Charles Fleischman, and James Rebitzer, "Job-Hopping in Silicon Valley: Some Evidence Concerning the Microfoundations of a High-Technology Cluster", Review of Economics and Statistics 88:3 (2006), 472-481.

Figueiredo, Octávio, Paulo Guimaraes, and Douglas Woodward, "Home-Field Advantage: Location Decisions of Portuguese Entrepreneurs", Journal of Urban Economics 52:2 (2002), 341-361.

Figueiredo, Octávio, Paulo Guimaraes, and Douglas Woodward, "Localization Economies and Establishment Size: Was Marshall Right after All?”, Journal of Economic Geography 9 (2009), 853-868.

Fritsch, Michael, and Michael Wyrwich, "The Long Persistence of Regional Entrepreneurship Culture: Germany 1925-2005”, JENA Working Paper 2012-036 (2012).

Furman, Jeffrey, Michael Porter, and Scott Stern, "The Determinants of National Innovative Capacity", Research Policy 31:6 (2002), 899-933.

Furth, Salim, "Why the Slow Economic Recovery?", Heritage Foundation Issue Brief (2012).

Gennaioli, Nicola, Rafael La Porta, Florencio Lopez-de-Silanes, and Andrei Shleifer, "Human Capital and Regional Development", Quarterly Journal of Economics (2012), forthcoming.

Ghani, Ejaz, William Kerr, and Stephen O'Connell, "Local Industrial Structures and Female Entrepreneurship in India", Journal of Economic Geography (2013), forthcoming.

Ghani, Ejaz, William Kerr, and Stephen O'Connell, "Spatial Determinants of Entrepreneurship in India”, NBER Working Paper 17514 (2011).

Glaeser, Edward, and Joshua Gottlieb, "The Economics of Place Making Policies", Brookings Papers on Economic Activity 2008:1 (2008), 155-239. 
Glaeser, Edward, Hedi Kallal, José Scheinkman, and Andrei Shleifer, "Growth in Cities", Journal of Political Economy 100:6 (1992), 1126-1152.

Glaeser, Edward, Sari Kerr, and William Kerr, "Entrepreneurship and Urban Growth: An Empirical Assessment with Historical Mines", NBER Working Paper 18333 (2012).

Glaeser, Edward, and William Kerr, "Local Industrial Conditions and Entrepreneurship: How Much of the Spatial Distribution Can We Explain?", Journal of Economics and Management Strategy 18:3 (2009), 623-663.

Glaeser, Edward, William Kerr, and Giacomo Ponzetto, "Clusters of Entrepreneurship", Journal of Urban Economics 67:1 (2010), 150-168.

Glaeser, Edward, and Albert Saiz, "The Rise of the Skilled City", Brookings Wharton Papers on Urban Affairs 5 (2004), 47-94.

Gompers, Paul, Josh Lerner, and David Scharfstein, "Entrepreneurial Spawning: Public Corporations and the Genesis of New Ventures, 1986 to 1999”, Journal of Finance 60:2 (2005), 577-614.

Greenstone, Michael, Richard Hornbeck and Enrico Moretti, "Identifying Agglomeration Spillovers: Evidence from Winners and Losers of Large Plant Openings", Journal of Political Economy 118 (2010), 536-598.

Gutberlet, Theresa, "Cheap Coal, Market Access, and Industry Location in Germany 1846 to 1882", Working Paper (2013).

Haltiwanger, John, Ron Jarmin, and Javier Miranda, "Who Creates Jobs? Small vs. Large vs. Young", Review of Economics and Statistics (2012), forthcoming.

Hausman, Naomi, "University Innovation, Local Economic Growth, and Entrepreneurship”, Working Paper (2013).

Hunt, Jennifer, and Marjolaine Gauthier-Loiselle, "How Much Does Immigration Boost Innovation?", American Economic Journal: Macroeconomics 2:2 (2010), 31-56.

Hurst, Eric, and Ben Pugsley, "What Do Small Businesses Do?”, Brookings Papers on Economic Activity (2012), forthcoming.

Jofre-Monseny, Jordi, Raquel Marín-López, and Elisabet Viladecans-Marsal, "The Mechanisms of Agglomeration: Evidence from the Effect of Inter-Industry Relations on the Location of New Firms", Journal of Urban Economics 70:2-3 (2011), 61-74.

Kenney, Martin, Understanding Silicon Valley: The Anatomy of an Entrepreneurial Region (Palo Alto, CA: Stanford University Press, 2000).

Kerr, William, "Breakthrough Inventions and Migrating Clusters of Innovation", Journal of Urban Economics 67:1 (2010a), 46-60.

Kerr, William, "The Agglomeration of U.S. Ethnic Inventors", in Glaeser, Edward (ed.) Agglomeration Economics (Chicago, IL: University of Chicago Press, 2010b), 237-276.

Kerr, William, Josh Lerner, and Antoinette Schoar, "The Consequences of Entrepreneurial Finance: Evidence from Angel Financings", Review of Financial Studies (2013), forthcoming.

Kerr, William, and William Lincoln, "The Supply Side of Innovation: H-1B Visa Reforms and U.S. Ethnic Invention”, Journal of Labor Economics 28:3 (2010), 473-508.

Kerr, William, and Scott Kominers, "Agglomerative Forces and Cluster Shapes”, NBER Working Paper 16639 (2010).

Kerr, William, and Ramana Nanda, "Democratizing Entry: Banking Deregulations, Financing Constraints, and Entrepreneurship", Journal of Financial Economics 94 (2009), 124-149.

Kerr, William, and Ramana Nanda, "Financing Constraints and Entrepreneurship", in Audretsch, David, Oliver Falck, and Stephan Heblich (eds.) Handbook of Research on Innovation and Entrepreneurship (Cheltenham, U.K.: Edward Elgar Publishing, 2011), 88-103.

Klapper, Leora, Raphael Amit, and Mauro F. Guillén, "Entrepreneurship and Firm Formation across Countries", in Lerner, Josh, and Antoinette Schoar (eds.) International Differences in Entrepreneurship (Chicago, IL: University of Chicago Press, 2010). 
Klepper, Steven, "The Origin and Growth of Industry Clusters: The Making of Silicon Valley and Detroit", Journal of Urban Economics 67 (2010), 15-32.

Kline, Patrick, and Enrico Moretti, "Local Economic Development, Agglomeration Economies and the Big Push: 100 Years of Evidence from the Tennessee Valley Authority", Working Paper (2012).

Kortum, Samuel, and Josh Lerner, “Assessing the Contribution of Venture Capital to Innovation”, RAND Journal of Economics 31:4 (2000), 674-692.

Lee, James, and Tom Nicholas, "The Origins and Development of Silicon Valley", Harvard Business School Case 813-098 (2012).

Lerner, Josh, "When Bureaucrats Meet Entrepreneurs: The Design of Effective 'Public Venture Capital' Programmes", Economic Journal 112 (2002), F73-F84.

Lerner, Josh, Boulevard of Broken Dreams (Princeton, NJ: Princeton University Press, 2009).

Link, Albert, and John Scott, "The Growth of Research Triangle Park”, Small Business Economics 20:2 (2003), $167-175$.

Marshall, Alfred, Principles of Economics (London, UK: MacMillan and Co., 1920).

Marx, Matt, Debbie Strumsky, and Lee Fleming, "Mobility, Skills, and the Michigan Non-Compete Experiment", Management Science 55:6 (2009), 875-889.

Michelacci, Claudio, and Olmo Silva, "Why So Many Local Entrepreneurs?", Review of Economics and Statistics 89:4 (2007), 615-633.

Moretti, Enrico, "Workers' Education, Spillovers and Productivity: Evidence from Plant-Level Production Functions", American Economic Review 94:3 (2004).

Mukim, Megha, "Industry and the Urge to Cluster: A Study of the Informal Sector in India", Spatial Economics Research Centre Discussion Paper 0072 (2011).

Murata, Yasusada, Ryo Nakajima, Ryosuke Okamoto, and Ryuichi Tamura, "Localized Knowledge Spillovers and Patent Citations: A Distance-Based Approach", Working Paper (2012).

Parker, Simon, The Economics of Entrepreneurship (Cambridge, UK: Cambridge University Press, 2009).

Porter, Michael, The Competitive Advantage of Nations (New York: Free Press, 1990).

Porter, Michael, "Clusters and Economic Policy: Aligning Public Policy with the New Economics of Competition", Harvard Business School Paper (2007).

Puri, Manju, and Rebecca Zarutskie "On the Lifecycle Dynamics of Venture-Capital- and Non-Venture-CapitalFinanced Firms", Journal of Finance (2012), 2247-2294.

Rauch, James, "Productivity Gains from Geographic Concentration of Human Capital: Evidence from the Cities", Journal of Urban Economics 34 (1993), 380-400.

Rosenthal, Stuart, and William Strange, "The Determinants of Agglomeration", Journal of Urban Economics 50 (2001), 191-229.

Rosenthal, Stuart, and William Strange, "Geography, Industrial Organization, and Agglomeration", Review of Economics and Statistics 85:2 (2003), 377-393.

Rosenthal, Stuart, and William Strange, "Evidence on the Nature and Sources of Agglomeration Economies", in Vernon Henderson and Jacques François Thisse (eds.) Handbook of Regional and Urban Economics, Volume 4 (Amsterdam: North-Holland, 2004), 2119-2171.

Rosenthal, Stuart, and William Strange, "Small Establishments/Big Effects: Agglomeration, Industrial Organization and Entrepreneurship", in Glaeser, Edward (ed.) Agglomeration Economics (Chicago, IL: University of Chicago Press, 2010).

Rosenthal, Stuart, and William Strange, "Female Entrepreneurship, Agglomeration, and a New Spatial Mismatch", Review of Economics and Statistics 94:3 (2012), 764-788.

Samila, Sampsa, and Olav Sorenson, "Venture Capital, Entrepreneurship and Economic Growth", Review of Economics and Statistics 93:1 (2011), 338-349.

Saxenian, AnnaLee, Regional Advantage: Culture and Competition in Silicon Valley and Route 128 (Cambridge, MA: Harvard University Press, 1994). 
Saxenian, AnnaLee, Silicon Valley's New Immigrant Entrepreneurs (Public Policy Institute of California, 1999).

Schoar, Antoinette, "The Divide Between Subsistence and Transformational Entrepreneurship", in Lerner, Josh, and Scott Stern (eds.) Innovation Policy and the Economy, Number 10 (Chicago, IL: University of Chicago Press, 2009), 57-71.

Simon, Curtis, "Human Capital and Metropolitan Employment Growth", Journal of Urban Economics 43:2 (1998), 223-243.

Simon, Curtis, and Clark Nardinelli, "Human Capital and the Rise of American Cities, 1900-1990", Regional Science and Urban Economics 32:1 (2002), 59-96.

Stephan, Paula, and Sharon Levin, "Exceptional Contributions to US Science by the Foreign-Born and ForeignEducated", Population Research and Policy Review 20:1 (2001), 59-79.

Zhao, Bo, and Rosemarie Ziedonis, "State Governments as Financiers of Technology Startups: Implications for Firm Performance", Working Paper (2012).

Zucker, Lynne, Michael Darby, and Marilynn Brewer, "Intellectual Human Capital and the Birth of U.S. Biotechnology Enterprises", American Economic Review 88 (1998), 290-306. 


\section{Fig. 1: City employment growth and initial entrepreneurship}

\section{Cross-sectional plots of urban growth 1982-2002 vs. initial traits}
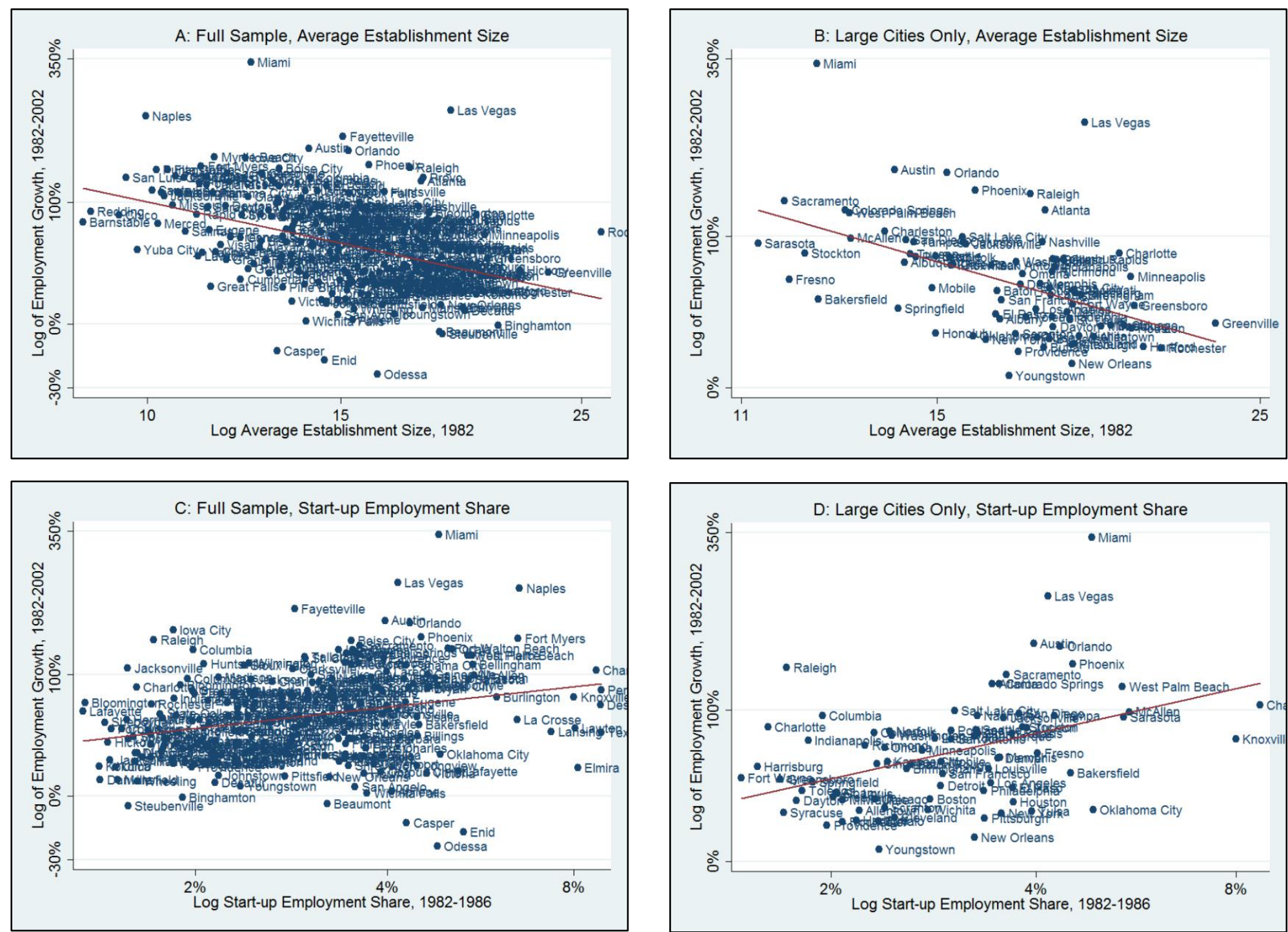

Notes: Taken from Glaeser, Kerr, and Kerr (2012). Figure presents city employment growth over the 1982-2002 period against measures of local entrepreneurship in 1982. Panels A and B use average establishment size, with places with smaller establishments associated with greater subsequent growth. Panels $C$ and $D$ use start-up entry rates, with places with greater start-up shares showing greater subsequent growth. 
Fig. 2: Dimensions of government policy

\begin{tabular}{|c|c|c|c|}
\hline \multirow{4}{*}{ 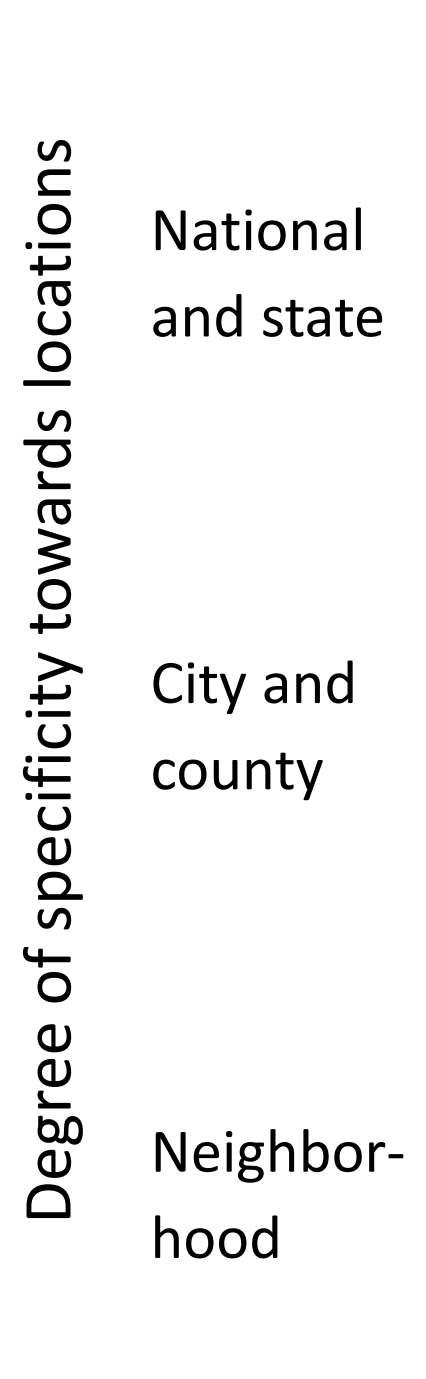 } & General & Industries/sectors & Firms \\
\hline & $\begin{array}{l}\text { Overall tax code } \\
\text { Patent policy } \\
\text { Non-compete clauses }\end{array}$ & $\begin{array}{l}\text { Industry-specific tax } \\
\text { provisions, e.g. film } \\
\text { industry subsidies } \\
\text { Research subsidies }\end{array}$ & $\begin{array}{l}\text { National and state loan } \\
\text { guarantees for specific } \\
\text { firms, e.g. Solyndra }\end{array}$ \\
\hline & $\begin{array}{l}\text { Citywide taxes and } \\
\text { business regulations } \\
\text { Inter-urban } \\
\text { transportation }\end{array}$ & $\begin{array}{l}\text { New York City industrial } \\
\text { support for life science } \\
\text { or fashion industries, } \\
\text { tax breaks for finance } \\
\text { industry }\end{array}$ & $\begin{array}{l}\text { City-level tax breaks for } \\
\text { million-dollar plants } \\
\text { Contracts tied to local } \\
\text { firms }\end{array}$ \\
\hline & $\begin{array}{l}\text { Empowerment Zones } \\
\text { Local infrastructure }\end{array}$ & $\begin{array}{l}\text { Innovation clusters } \\
\text { Industry-specific local } \\
\text { infrastructure }\end{array}$ & $\begin{array}{l}\text { Firm-specific } \\
\text { infrastructure }\end{array}$ \\
\hline
\end{tabular}




\section{Fig. 3: City patenting growth after breakthrough inventions}

\section{Ten largest cities per technology split by their breakthrough share}

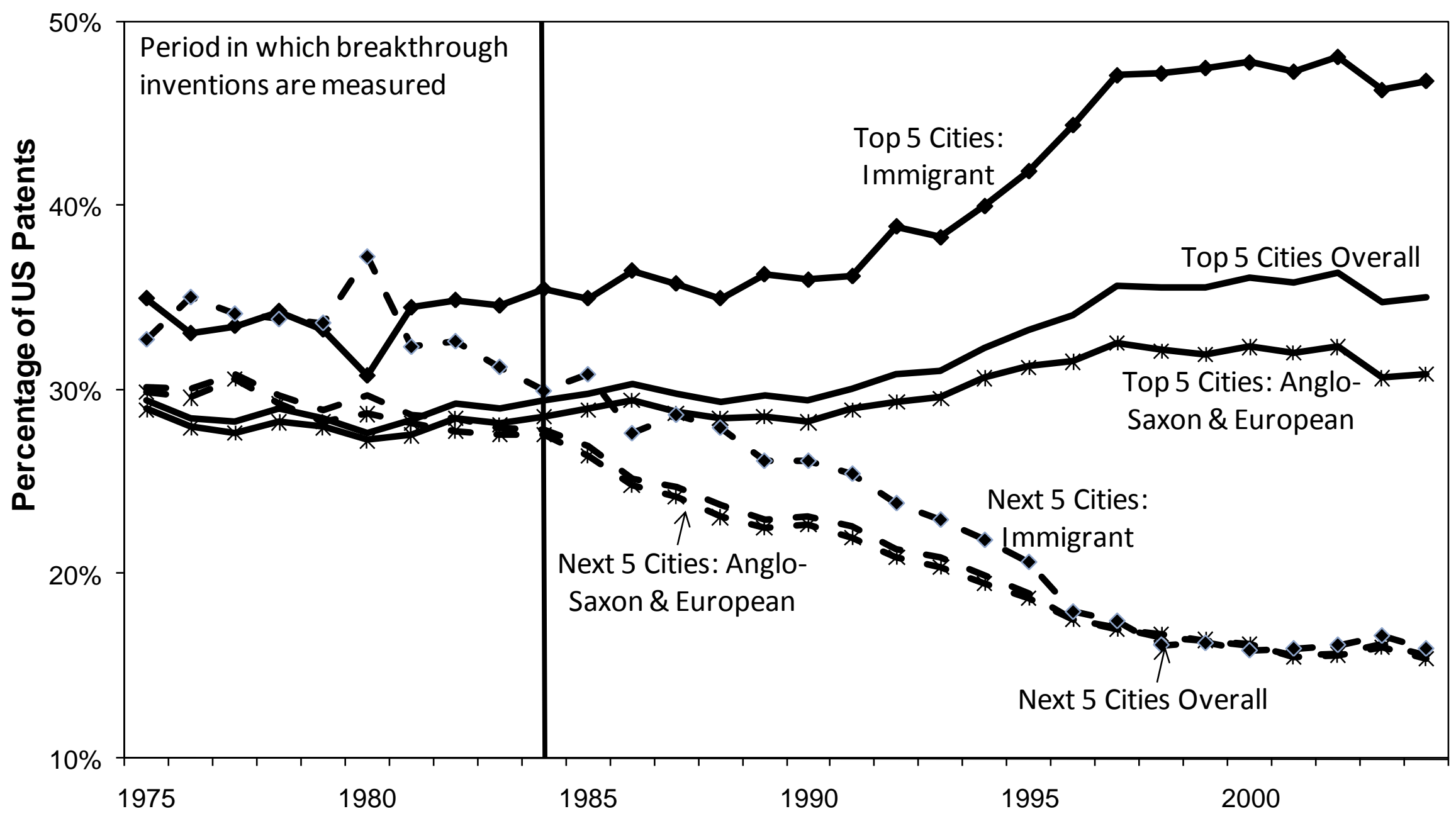

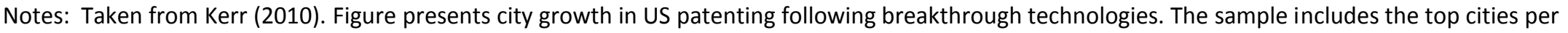

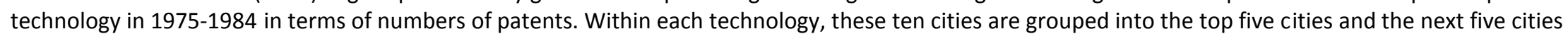

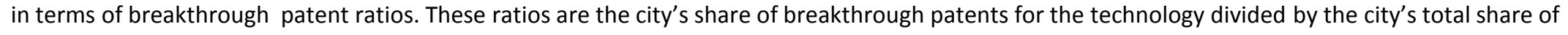

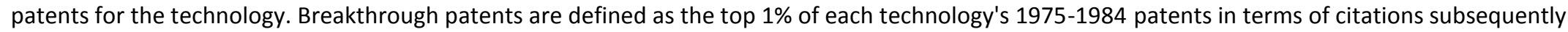
received. Included city-technology pairs are held constant to measure the migration of innovation following breakthroughs. Shares for Anglo-Saxon/

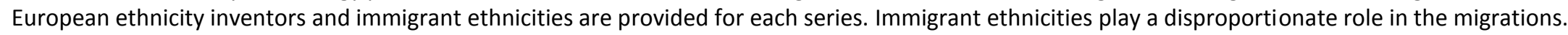




\section{Fig. 4: Spatial concentration of venture capital investments, 2011}

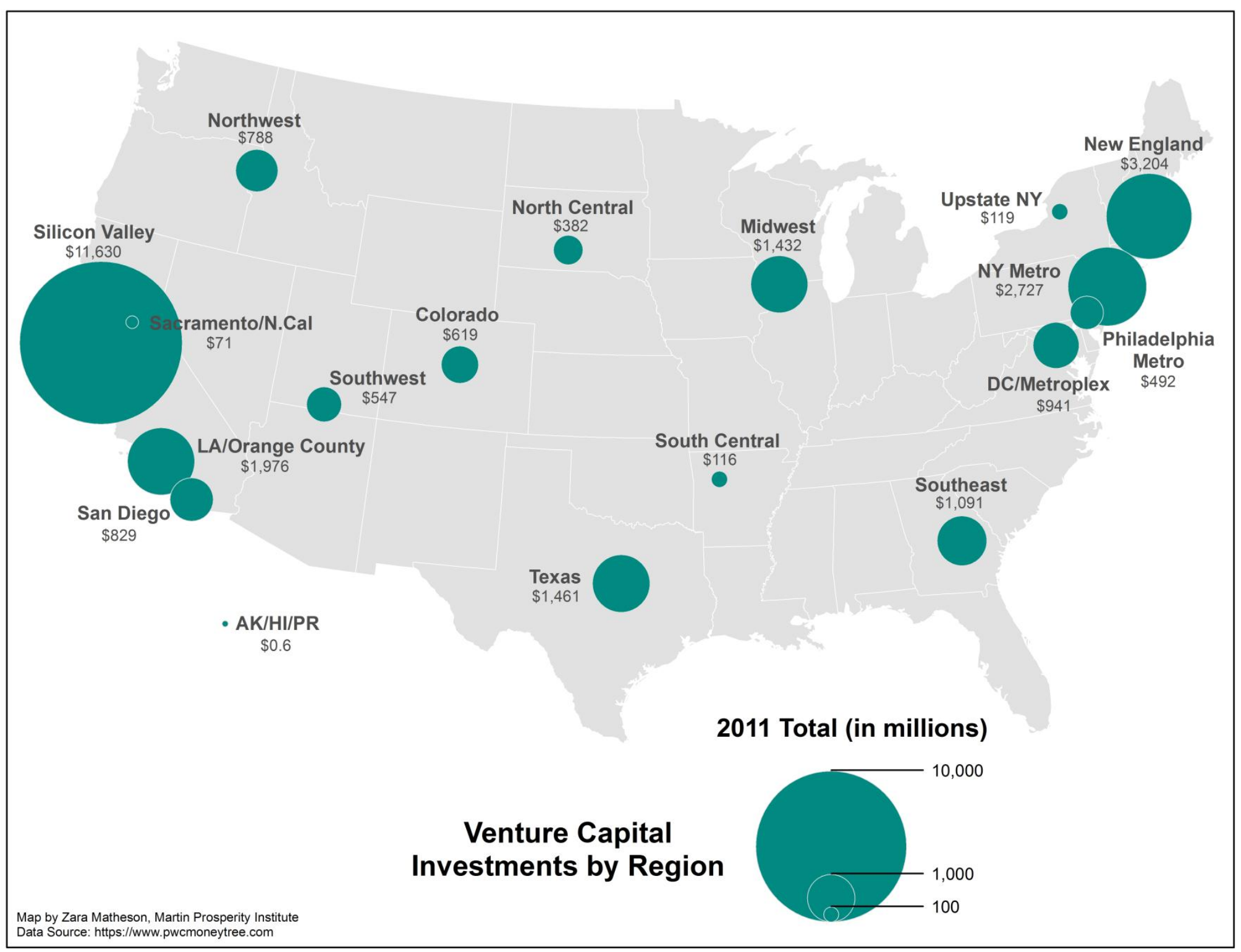

Notes: Taken from Martin Prosperity Institute's Zara Matheson and based upon PWC MoneyTree data. 
Fig. 5: Spatial concentration of U.S. venture capital and patenting

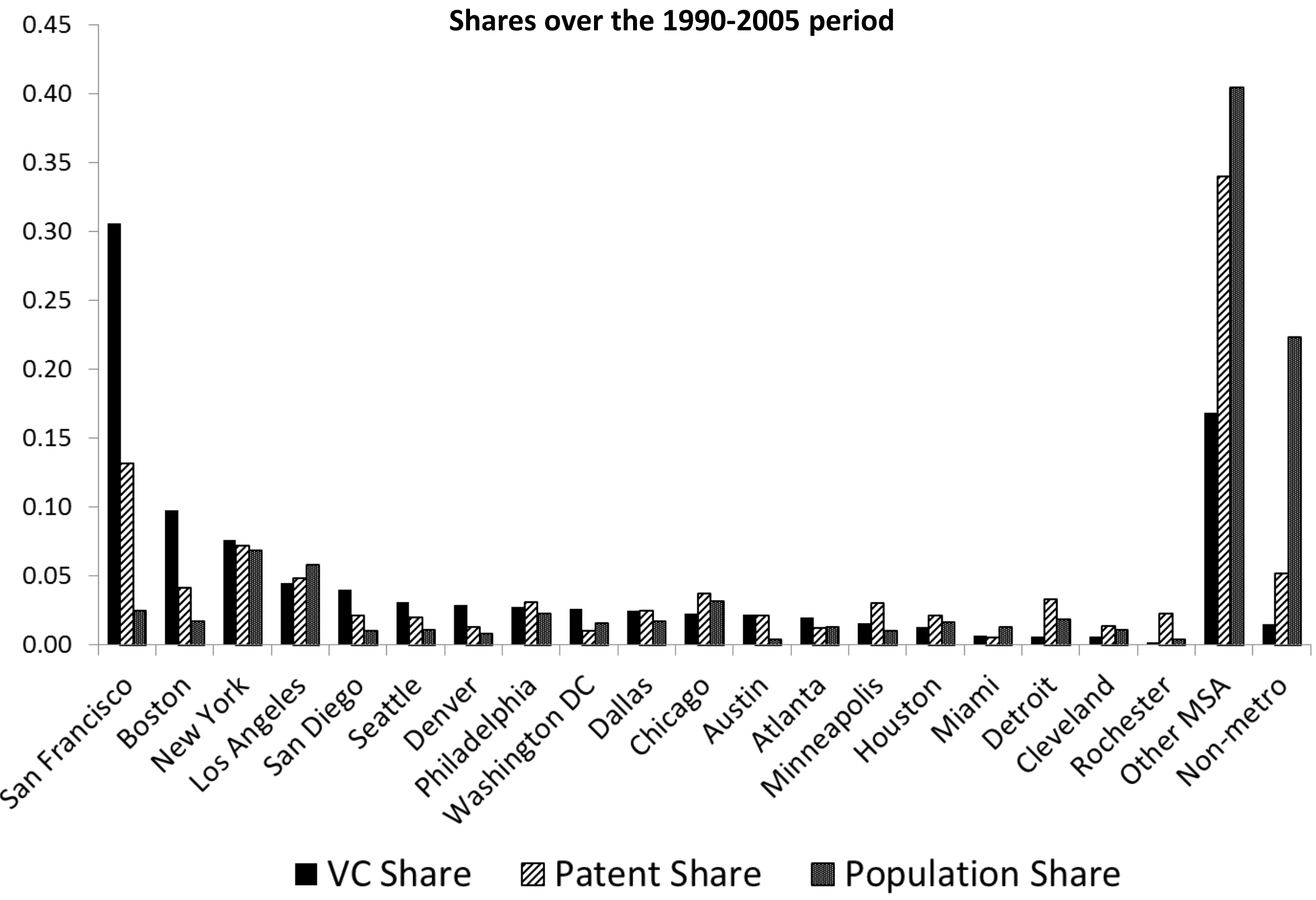

Notes: Calculated by the authors from Venture Xpert, USPTO patent data, and county-level population statistics. VC calculations use share of deals over the 1990-2005 period. Patent calculations use share of granted patents applied for from each city during 1990-2005. Population share is from 1999. 